\title{
European Societies
}

E U R O P E A N

SOCIETIES

\section{Sociology in Poland: to be continued?}

\section{Mikołaj Pawlak}

To cite this article: Mikołaj Pawlak (2017) Sociology in Poland: to be continued?, European Societies, 19:1, 113-115, DOI: 10.1080/14616696.2016.1235220

To link to this article: https://doi.org/10.1080/14616696.2016.1235220

曲 Published online: 21 Sep 2016.

Submit your article to this journal $₫$

Џll Article views: 105

Q View related articles $\llbracket$

View Crossmark data $\nearrow$ 


\section{BOOK REVIEWS}

\section{Sociology in Poland: to be continued?, by Bucholc, Marta, London,} Palgrave Macmillan, 2016, IX + 102 pp., €53.49 (hardback), ISBN 978-1-13758186-0

In Sociology in Poland, Marta Bucholc presents the last 70 years of sociology in the country troubled by large social transformations, which impacted the institutional base and academic style of its universities. The author is a historian of sociological theory trained in Poland and currently based in Germany, which allows her to tackle the Polish sociological field from the position of both an insider and an outsider.

Sociology in Poland describes the institutions and practices of Polish sociology since the Second World War to the present day. Polish sociology is quite selfabsorbed and there are already available several studies of various aspects of its history written in the Polish language. These studies are used by Bucholc as sources to tell a condensed story of sociology in Poland. The parts of the book describing the recent past, the present and the future are mostly based on observations of the author and some statistics regarding Polish academia. The main statement of the book is that sociologists in Poland throughout the twentieth century as well as today are caught in the tension between local engagement and international academic excellence. The interplay of parochial and universal is, according to Bucholc, what has shaped the sociological field in Poland - a semi-peripheral country with semi-peripheral social sciences. The very important context for sociology in Poland is that it is the intelligentsia's enterprise. The intelligentsia is a social class founded on its cultural capital with a strong ethos of social engagement that emerged in East European societies. Although Bucholc does not say so directly, from her book we can sense that in Poland sociology provides just another language for the intelligentsia to debate the social issues of their homeland.

In the book, Bucholc describes how societal changes in Poland (including the Second World War, communist rule, and eventually transition to democracy and market economy) have influenced sociology. Various social roles, which academic sociologists have been taking up, are presented: survivors from pre-war academia, supervisors of the Marxist ideology, and public intellectuals in mediatized late modern democracy. Bucholc provides evidence for her statement that the fall of communism in 1989 did not result in any discontinuity of sociology in Poland. She shows that the institutional basis of sociology has remained the same since the organizational reforms of academia implemented after the events of the year 1968. Her arguments are supported by data on numbers of publications, enrolment to sociological programmes at universities and the financing of science. 
The book is written in a vivid language and discusses both the parochialism and the dream of universal consequentiality of Polish sociologists in a persuasive way. It elegantly presents the entanglement of sociologists in the transformations of society that they have been attempting to explain to itself. The book summarizes and extends the already quite rich self-description of Polish sociology.

Bucholc's book is a very good testimony of sociology in Poland, yet there are two aspects to which critique needs to be pointed: consequences of the methodological framing of sociology, and the paradoxical reaction to the recent reforms of science in Poland. Bucholc treats sociologists as 'people who believed themselves to be, or were believed by others to be sociologists' (2) - a social definition of sociologists indeed! Yet at the same time, she laments that sociology in Poland, at least since 1970s, has not been sufficiently interdisciplinary and problem-oriented. I would argue that problem-oriented research strategies undertaken by interdisciplinary research teams are also present in Polish social sciences but they are often not carried out under the label of sociology. A good example is migration studies recently developing successfully in Poland as a common effort by economists, anthropologists, historians, political scientists, and sociologists. In the past, a similar problem-oriented approach was jointly undertaken by trained lawyers, educationists and sociologists in the frame of the applied social science designed by Adam Podgórecki as a sociotechnique, which attracted some international attention in the 1970s. The methodological decision to focus on what is called sociology (and that often highlights its sociological identity) causes the risk of omitting scholarly activities strongly informed by sociological theory and methodology but less obsessed with its sociological-ness.

I am convinced that in her assessment of the recent global changes of science, which in Poland are manifested by the so-called neo-liberal reforms, Bucholc is trapped by the paradoxical nature of the Polish sociologist trying simultaneously to be locally relevant and universally up-to-date. On the one hand, she expresses her scepticism about the reforms and 'neo-liberal obsession with numbers and forms' (85). But on the other hand, she praises all the signs of catching up with the international science community and sometimes even adopts the managerial frames of thinking about science. A good example would be that when describing the names of past Polish sociological community leaders (such as Maria Ossowska, Stefan Nowak or Józef Chałasiński), many people are cited and their scholarly excellence is praised. Yet, when regarding the generation of younger sociologists whose careers are still unfolding only the name of Natalia Letki is mentioned, because she received an ERC research grant. Yet, this ambivalence is unavoidable and actually serves as an example of a key statement of the book.

As noted recently by Jarosław Kilias, Polish sociology speaks foreign languages mostly to itself. I am sure that it is not going to be the case with Bucholc's book. Authors describing the field to which they belong are always trapped in an insider-outsider paradox. Bucholc is also a part of the phenomenon under investigation: she explains to an international audience the tensions she herself has experienced as a sociologist trained in Poland when discussing the country's social issues in Polish, while aspiring to international academic excellence. She has managed to deal with this paradox successfully and her book is an excellent 
guide to a meaningful understanding of the ups-and-downs of sociology in Poland.

\section{Mikołaj Pawlak \\ University of Warsaw, Poland \\ (2) mikolajpawlak@uw.edu.pl (D) http://orcid.org/0000-0003-1727-4342}

(C) 2016 Mikołaj Pawlak

http://dx.doi.org/10.1080/14616696.2016.1235220

\section{Imagined futures: fictional expectations and capitalist dynamics, by Jens Beckert, Cambridge, MA, Harvard University Press, 2016, ix + 373 pp., \$39.95, ISBN-10: 0674088824}

Beckert's book makes the argument that capitalist dynamics are grounded in processes of imagining the future and of creating and revising expectations that motivate actors to engage in economic actions. Imagined Futures is a book about the microfoundations of capitalism. It shows that in order to understand the amplitude and crises of capitalism, we ought to grasp the agency of actors, and not just the impact of great structural forces and tendencies. But Imagined Futures is also a book that revises the habitual framing of these microfoundations. It argues that economic and sociological perspectives that posit that the expectations of economic actors are rational or socially determined are sort of outdated or not universally applicable. These analytical traditions overlook the fact that the decisions to engage in economic actions are increasingly taken in conditions of uncertainty or that they carry the possibility of creative destruction. Hence, we instead need a model of action that proceeds from contingent expectations.

Thus, the book does two things. It further clarifies the linkage between economic action and capitalist dynamics. And it proposes a new action theory. Instead of a model based on calculation and available information, or on habits, it introduces a model of action motivated by fictional expectations that are subjected to various social constraints. In terms of its structure, these two tasks are accomplished in three main parts, comprising of 11 chapters, including the introductory and concluding ones. The first part, on decision-making in an uncertain world, articulates an economic sociology of expectations and introduces the notion of fictional expectations. The second part, on the four building blocks of capitalism (money and credit, investments, innovation, and consumption), shows that in order to function they all need fictional expectations that are part of a collective belief. The third part, on the instruments of fictional expectations, discusses the role of forecasting and economic theory in terms of coordinating the social actors in times of uncertainty and in creating novelty. The overall conclusions again stress the theoretical value of the concept of fictional expectations. They also emphasize the importance of analyzing the microfoundations of capitalism and highlight that the motivation to engage in economic action should not be taken for granted. 